UDC 621.391

\title{
REFINED METHOD OF DETERMINING THE LOCATION OF THE SOURCERADIATION ON A CURVE WAVE FRONT
}

\author{
Evgeniy A.Yakornov, Oleg F. Tsukanov \\ National Technical University of Ukraine "Igor Sikorsky Kyiv Politechnic Institute", Kyiv, Ukraine
}

Background. Despite the limited range, the device determines the location of the radio source along the curved front of the electromagnetic wave, allows using the diversity antenna system to solve the problem of the simultaneous determination of range and direction of the radio source based on the curvature of the received electromagnetic wave front. For determining the calculation of the angular direction, a phase shift occurs due to the difference between the received electromagnetic wave front and the range - due to the curved wave front. The problem is solved in two stages: the angular direction is determined on the first stage and the range - on the second one, - so the method has high accuracy.

Objective. Development of a method to simultaneously determine the location of the radio source by measuring phase shifts which in addition allows to improve the accuracy of the positioning.

Methods. The proposed method is based on the use of refined forms of formula to define a range and an angular direction by measuring phase shifts, including those due to the curved front of the electromagnetic wave. The sought parameters are determined by finding the unconditional extremum of the local nonlinear formula for determining the distance and angular direction method of Hooke-Jeeves.

Results. The proposed positioning method allows simultaneous determination of radio-frequency source parameters and improves the location accuracy compared to existing methods by $3-8 \%$.

Conclusions. The method can be easily implemented in wide-band radio-frequency source searching devices of both existing and advanced telecommunication systems.

Keywords: curved wave front; phase shift; radio source; the antenna system; the wavelength; angular direction; distance of the radio source; the method of Hooke-Jeeves.

\section{Introduction}

In recent years, the definition of the location of the radio emission source (RES) devices which are widely used in telecommunication systems (TCS), in particular for monitoring the use of radio frequency spectrum [1]. Despite the limited range of operation such devices allow with using resonant antenna system (AS) to solve the problem simultaneous determination of the range $(\mathrm{R})$ and the direction on $\operatorname{RES}(\theta)$ on the base of including curvature front of the received electromagnetic wave(EMW).

In works $[2,3]$ the problem of measurement of the RES location based on the results of situating of the double phase difference between sparse receiving antenna of the curved front received by EMW is solved. To determine the angular direction the phase shift that occurs due to the direction difference of the received EMW front, and the distance - due to a curved wave front is calculated. This problem is solved in two ranges, the first one defines angular direction, while the second one defines the range. A method for simultaneous determination of RES position by measuring the phase shift is suggested that more over can improve the accuracy of determining the location of the RES.

\section{Formulation of the research task}

Let's study the AS (Fig. 1), that consists of $2 \mathrm{M}+1$ receiving antennas. If RES is the far-field region (FFR) [4]: $\mathrm{R}>2 \mathrm{~L}^{2} \sin ^{2} \theta / \lambda$,

where: $\lambda$ - is the wave length, $L$ - antennas' system length, so the direction of EMW waves to the antennas' system is equal and coincide with the direction of $\theta_{0}$.

For the better comprehension, we consider the central antenna as a zero, though the numbering of the rest of antennas to the right of zero will be with the sign "plus" and to the left - with the sign "minus".

$$
\theta_{-M}=\theta_{-M+1} \ldots=\theta_{0}=\ldots \theta_{M+1}=\theta_{M} .
$$

In case if RES is in the nearest - field region (NFR) AS,

$$
2 \rho_{i}^{2} \sin ^{2} \theta_{i} / \lambda<\mathrm{R}<2 L^{2} \sin ^{2} \theta / \lambda
$$

Where: $\rho_{i}, \theta_{i}-$ the distance between the partial antennas and the direction of the source regarding it, the direction $\theta_{i}$ of waves' destination on all the elementary antennas are different (Fig. 1), $i=\overline{-M, M}$. The last formula shows at what values of RES range will be in the Fresnel zone of the AS, but at the same time remains in the FFR of any partial antenna. 


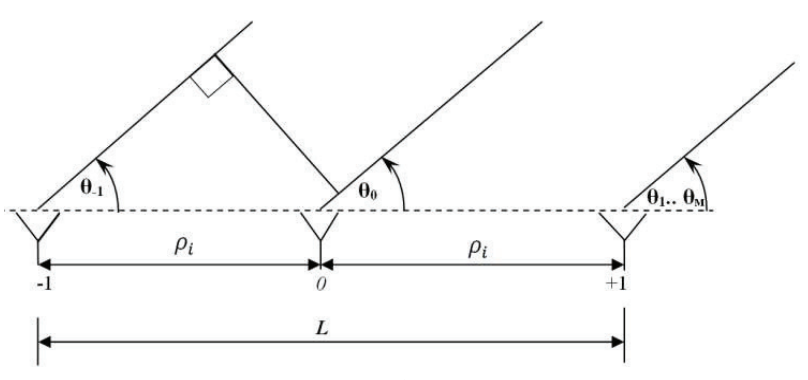

Fig.1

Conditions corresponding to the maximum values FFR $R_{F F R}$ and NFR $R_{\mathrm{NFR}}$ for all value types of angles $\theta$

$$
R_{F F R}=2 L^{2} / \lambda, R_{N F R}=0.38 L^{3} / \lambda \text {. }
$$

In the case of the presence in AS of three or more receive antennas, RES location can be determined from the formula [2]:

$$
\Psi(L, R)=\mathrm{R}-\mathrm{L} \cos \theta+\frac{\mathrm{L}^{2} \sin \theta^{2}}{2 R}
$$

The sense of the task formulates as follows:

1. Basing on (2) define the conditions under which may be defined values $\mathrm{R}$ and $\theta$.

2. Improve the positioning accuracy by using a refined formula (2).

Multiplying the left and right sides (2) by $\frac{2 \pi}{\lambda}$ and assuming, that the phase offset between neighboring antennas:

will define:

$$
\Delta \varphi=\frac{2 \pi}{\lambda} \Psi(\mathrm{L}, \mathrm{R})-\frac{2 \pi}{\lambda} \mathrm{R},
$$

$$
\Delta \varphi=-2 \pi \frac{\mathrm{L}}{\lambda} \cos \theta+\frac{2 \pi \mathrm{L}^{2} \sin \theta^{2}}{2 \mathrm{R} \lambda}
$$

finally obtain the quadratic equation to: $\theta$ :

$$
\frac{\pi \mathrm{L}^{2} \sin \theta^{2}}{\lambda R}-2 \pi \frac{\mathrm{L}}{\lambda} \cos \theta-\Delta \varphi=0
$$

Let's define the conditions under which the equation (3) will have a solution. It is known, that if the discriminant of the quadratic equation is positive, then the last one has two roots. It would be desirable to have the values of these roots as $R$ and $\theta$, but in the equation (3) $R$ and $\theta$ are unknown, and one $\theta$ is a root, supposed that the value of $R$ is known.

The magnitude of the phase offset $\Delta \varphi$, that is a part of the equation (3) can be represented as the sum of

$$
\Delta \varphi=\Delta \varphi^{\prime}+\Delta \varphi^{\prime \prime}
$$

where: $\Delta \varphi^{\prime}$ - the phase shift due to the difference between the receiving antennas,

$\Delta \varphi^{\prime \prime}$ - the phase shift due to the curvature of the phase front.

The definition of $\Delta \varphi^{\prime \prime}$ - will be different from zero only in the case of receiving EMW by the spherical front. If $\Delta \varphi$ " is known, the distance of $R$ to the RES determines:

$$
\mathrm{R}=\frac{\pi \mathrm{L}^{2} \sin \theta^{2}}{\lambda \Delta \varphi \prime \prime}
$$

In the compound (5) are included the value of the angular direction $\theta$, for the calculation of which is necessary to measure the value of $\Delta \varphi^{\prime \prime}$. To do this, determine the phase shift(phase progression) $\varphi$ between the outer antennas without disambiguation measurements.. The determination of EMW front curvature is calculated by a double-difference or the phase difference of the differences [2,3] between the receiving antennas. For example, three antennas with number $-1,0,1$ magnitude of the phase offset $\Delta \varphi$ " due to the curvature of the front is calculated as

$$
\Delta \varphi^{\prime \prime}=\Delta \varphi_{-10}-\Delta \varphi_{01},
$$

where: $\Delta \varphi_{-10}=\varphi_{-1}-\varphi_{0}$ - the phase difference between antennas -1 and $0, \Delta \varphi_{01}=\varphi_{0}-\varphi_{1}$ - the phase difference between antennas 1 and 0 , here $\varphi_{0}=0$.

When $R>2 L^{2} / \lambda$, the phase front of the received electromagnetic wave becomes flat, $\Delta \varphi^{\prime \prime}=0$, and the calculation of $\mathrm{R}$ in accordance with (5) is not possible.

To determine the angular direction $\theta$ phase difference $\Delta \varphi^{\prime}$ we can find as

$$
\Delta \varphi^{\prime}=\varphi_{-1}-\varphi_{1},
$$

where: $\varphi_{i}$ - the magnitude of the phase progression shift due to the difference of the rays' direction received by two antennas. The angular direction $\theta$ determines from the linear equation

$$
2 \pi \frac{\mathrm{L}}{\lambda} \cos \theta-\Delta \varphi^{\prime}=0
$$

To calculate $R$ basing on (5-7), it is necessary to calculate the value of the phase shift $\Delta \varphi "$ due to the curvature of the EMW and $\Delta \varphi^{\prime}$ - the phase progression due to receiving signal of sparse antenna.

Define the value of $\theta$, at which the equation (3) has a solution with a known already value of $R$.

Let's define

$$
a=\frac{\pi \mathrm{L}^{2}}{\lambda R}, \quad b=2 \pi \frac{\mathrm{L}}{\lambda}
$$

Then with the calculation of (3) we receive

$$
\begin{aligned}
& a \sin \theta^{2}-b \cos \theta-\Delta \varphi=0, \text { or } \\
& a \cos \theta^{2}+b \cos \theta+\Delta \varphi-a=0 .
\end{aligned}
$$

Note, that due to the fact that $a$ and $\Delta \varphi-a$ is less than $b$, discriminate (9) is always positive and accordingly, the equation (3) will always have a solution for all values of $\Delta \varphi^{\prime}$ 'except of the case when $\Delta \varphi$ " $=0$.

Consider a consistent method to determination the location of the RES:

1. Now we determine $\Delta \varphi "$ by the curvature of the front of EMW if the value is 0 , then is not possible to determine the value of

a). Calculate $\Delta \varphi^{\prime}$ to determine $\theta$.

b) Calculate $\Delta \varphi^{\prime \prime}$ to determine $R$.

c) Calculate sequentially value of $\theta$ and $R$ according to (5), (8)

2. The main disadvantage of this method is its low accuracy [5]. In addition, for its implementation, a rather rough approximation (3), the calculation is performed sequentially, that's why it is impossible to specify the value of $\theta$ at the calculated $R$ and vice versa. 
3. For some tasks, this approximation is quite acceptable, but there are a number of practical applications that require higher accuracy in determining of the location of the RES parameters.

\section{Research of detailed method of the positioning determination}

It is suggested a method of the positioning determination based on the refined form of formula (2). Let us base on a more complete form of formula (2), where it is taken into consideration the term of the Taylor series expansion, as follows:

$$
\Psi(\mathrm{L}, \mathrm{R})=\mathrm{R}-\mathrm{L} \cos \theta+\frac{\mathrm{L}^{2} \sin \theta^{2}}{2 R}+\frac{\mathrm{L}^{3} \cos \theta \sin \theta^{2}}{2 R^{2}} .
$$

Let's transform (10) in the same way (2) to

$$
-2 \pi \frac{\mathrm{L}}{\lambda} \cos \theta+\frac{\pi \mathrm{L}^{2} \sin \theta^{2}}{\lambda R}+\frac{\pi \mathrm{L}^{3} \cos \theta \sin \theta^{2}}{\lambda R^{2}}=\Delta \varphi
$$

To solve (11) it is necessary to find such values of $\theta, R$, at which the left side of the equation becomes equal to the right. This is a quadratic equation to $1 / \mathrm{R}$, and a non-linear to $\theta$. . Note that the analytical solution is very difficult, so find a solution by the number method.

We introduce the notifications:

$$
\begin{gathered}
\Delta \varphi^{\prime}=-2 \pi \frac{\mathrm{L}}{\lambda} \cos \theta=\mathrm{f}_{1}(\theta) ; \\
\Delta \varphi^{\prime \prime}=\frac{\pi \mathrm{L}^{2} \sin \theta^{2}}{\lambda R}=\mathrm{f}_{2}(\theta) ; \\
\Delta \varphi^{\prime \prime \prime}=\frac{\pi \mathrm{L}^{3} \cos \theta \sin \theta^{2}}{\lambda R^{2}}=\mathrm{f}_{3}(\theta) ; \\
\Delta \varphi=\Delta \varphi^{\prime}+\Delta \varphi^{\prime \prime}+\Delta \varphi^{\prime \prime \prime}=\mathrm{f}(\theta) .
\end{gathered}
$$

Let's make the graphics of the variation of the formula (11). For this we construct parameter change graphics (11) in accordance with (12) where $\mathrm{R}=40 \mathrm{~m} ., \lambda=3 \mathrm{~cm}, \mathrm{~L}=84 \mathrm{~cm}, \theta$ of from $10^{\circ}$ to $170^{\circ}$ on the abscissa where the scale is specified in degrees, which should be multiplied by 10 (Fig.2$5)$.

$$
\Delta \varphi=\mathrm{f}(\theta)
$$

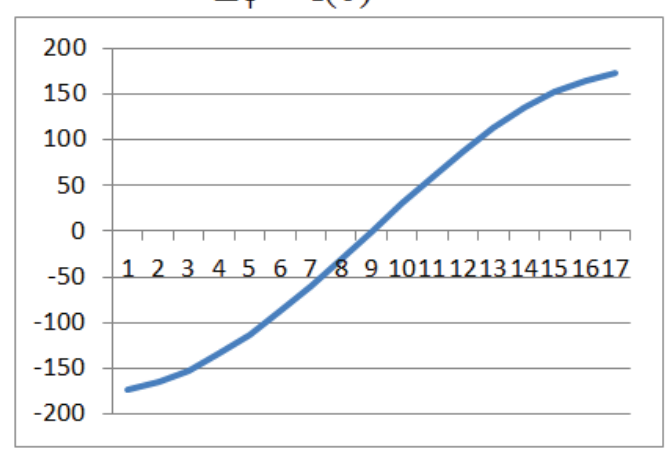

Fig. 2 Parameter $\Delta \varphi=\mathrm{f}(\theta)$

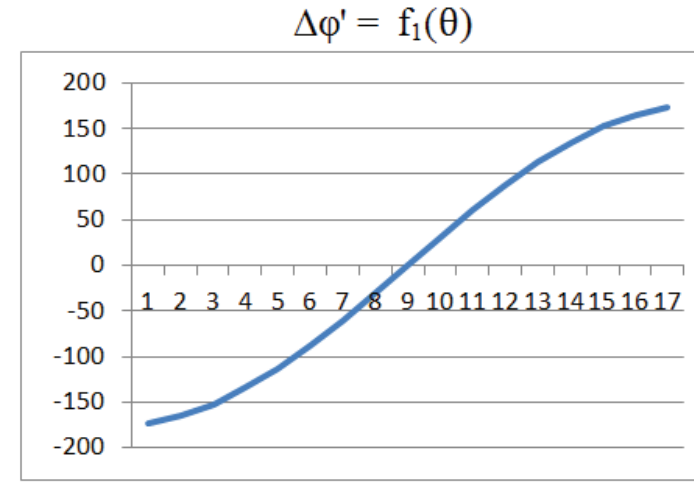

Fig.3 Parameter $\Delta \varphi^{\prime}=\mathrm{f}_{1}(\theta)$

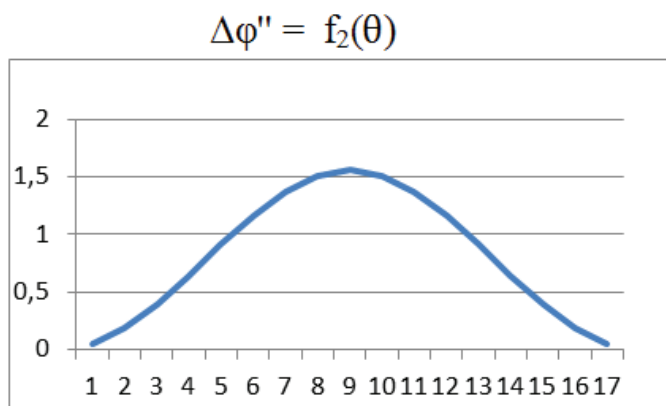

Fig.4 Parameter $\Delta \varphi^{\prime \prime}=\mathrm{f}_{2}(\theta)$

$$
\Delta \varphi^{\prime \prime \prime}=\mathrm{f}_{3}(\theta)
$$

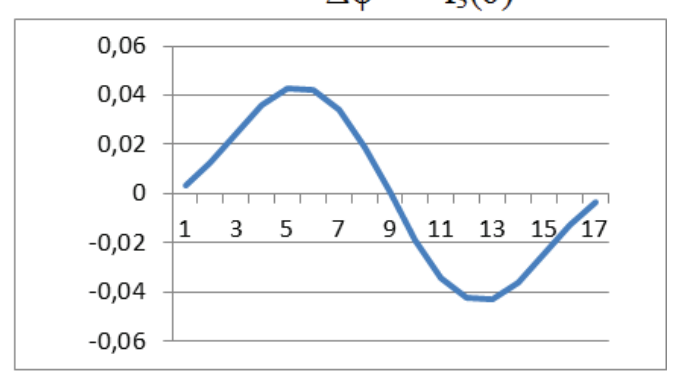

Fig.5 Parameter $\Delta \varphi^{\prime \prime \prime}=\mathrm{f}_{3}(\theta)$

As follows on the Fig. 5-9 are represented the parameter change graphics (11) where $\mathrm{R}=100 \mathrm{~m}, \lambda=10 \mathrm{~cm}$, $\mathrm{L}=280 \mathrm{~cm}$., $\theta$ of from $10^{\circ}$ to $170^{\circ}$ on the abscissa where the scale is specified in degrees, which should be multiplied by 10.

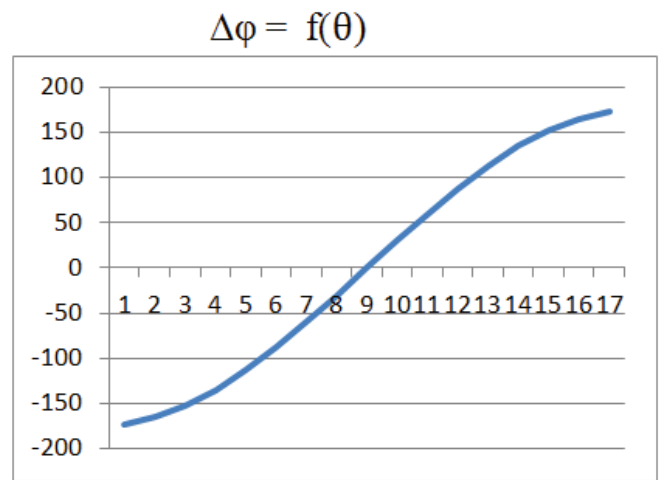

Fig.6 Parameter $\Delta \varphi=\mathrm{f}(\theta)$ 


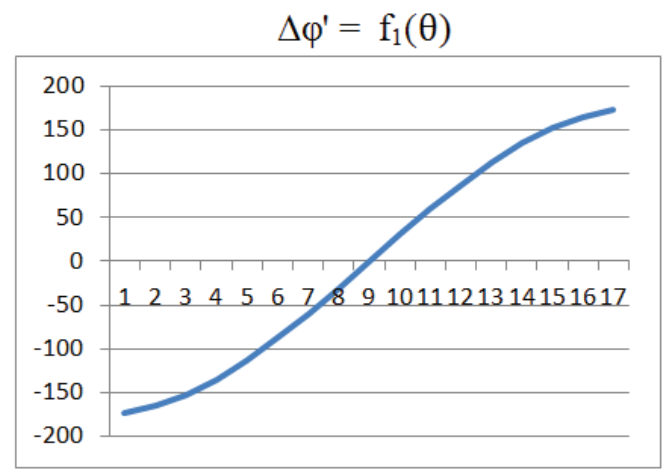

Fig.7 Parameter $\Delta \varphi^{\prime}=\mathrm{f}_{1}(\theta)$

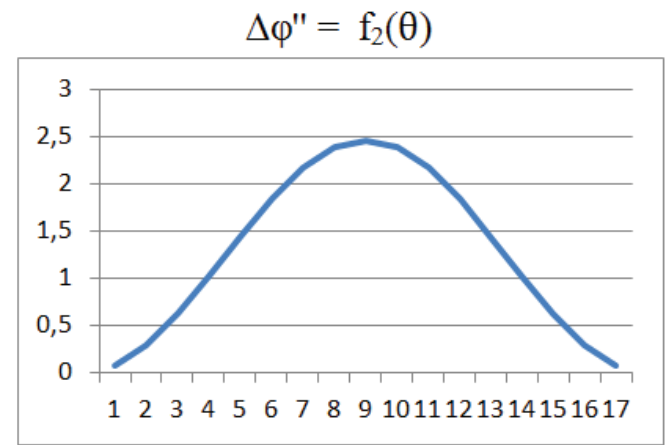

Fig.8 Parameter $\Delta \varphi^{\prime \prime}=\mathrm{f}_{2}(\theta)$

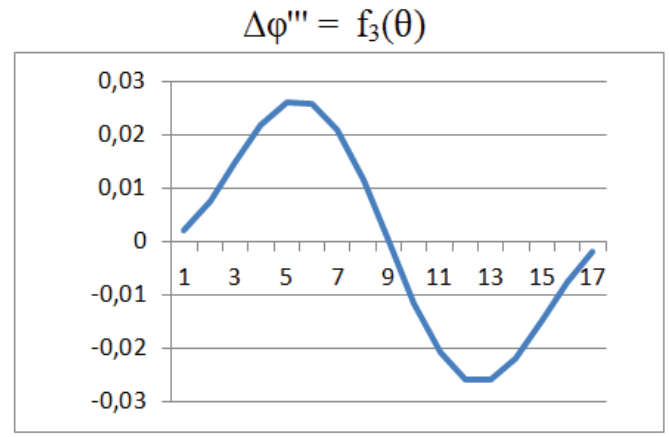

Fig.9 Parameter $\Delta \varphi^{\prime \prime}=\mathrm{f}_{3}(\theta)$

The second and third terms of formula (12) are nonmonotonous functions and comparing with the first term changes in a small range. This fact causes some difficulty in determining of the parameter $\Delta \varphi^{\prime \prime}$, the value of which one ranges from $0^{0}$ to $360^{\circ}$, and in the third term $\Delta \varphi^{\prime \prime}$ these changes begin from the second definition after the point. Therefore, it should be determined not by the angle $\theta$ in degrees, but in $\cos \theta$ and $\sin \theta$, (direction cosine and sine of the angle), and with an accuracy of at least 6 signs after point. For the definition of $R$ в in accordance with (5) the great value has the number of signs after point as for the value of $\Delta \varphi^{\prime \prime}$, and though for $\cos \theta$ and $\sin \theta^{2}$. While the division by a large number of $R$ should get a small number of $\Delta \varphi^{\prime \prime}$.

As $\Delta \varphi^{\prime \prime}$ and $\Delta \varphi^{\prime \prime \prime}$ is significantly less than $\Delta \varphi^{\prime}$, the Fig. 2.3 and Fig. 6.7. on the graphics these differences $\Delta \varphi=f(\theta)$ и $\Delta \varphi^{\prime}=-2 \pi \frac{\mathrm{L}}{\lambda} \cos \theta$ are not visible.
To determine $R$ и $\theta$ it is necessary to solve (11) by numerical method of determining the minimum value of a function of several variables. The graphics in Fig. 4,5,8,9 of the components (11) are non-linear functions, and therefore to determine the minimum (11) it is desirable not to use a gradient method.

Nowadays, there are a lot of methods that do not require a determination of not gradient signification, and the research of which one is more suitable is beyond the scope of this article. At the same time it is known that the most universal method of determining the extreme of the function is a method of HookeJeeves [5].

More over there is another advantage of the definition of the RES on the basis of numerical solution of the equation (9) that is the lack of need to calculate the value of $\Delta \varphi$ " and $\Delta \varphi$ "' separately for curved and flat wave front. It is possible from the results of measurements to determine the value $\Delta \varphi$. And due to the fact that $\theta$ is in all terms of function (9), and is calculated at the same time $R$, it can be argued that the proposed algorithm can also improve the accuracy of positioning parameters.

To reduce the time of determining the minimum value (9), it is proposed to divide the space in which is positioned RES into strips, $\Delta \theta_{1}, \Delta \mathrm{R}_{1} ; \Delta \theta_{2}, \Delta \mathrm{R}_{2} ; \ldots \Delta \theta_{\mathrm{n}}, \Delta \mathrm{R}_{\mathrm{n}}$ taking into account also (1). Splitting the measurement zone on the strip allows you to resolve simultaneously the ambiguity in the definition of coordinates.

Let's consider the algorithm in a given strip, where the initial conditions are the initial values of $\theta_{n 0}$ and $R_{n 0}$ and step $\theta_{h}$, and $R_{h}$ and the last values are constant values in each strip.

Further it is necessary to find (9) in each strip if it exists. It should be noted that as a result of the algorithm we obtain two pairs of values $\theta_{i}, \mathrm{R}_{i}$, positive and negative. The next step is the determining the true values $\theta_{i}, \mathrm{R}_{i}$ or false rejection. With the $\mathrm{R}$ value, there is no problem, it is taken into consideration only a positive true result. As for the variable $\theta$, its rejection is performed by determining the minimum difference between the values obtained with the not exact value(rough) $\theta_{i} \theta_{r g}$.

The value

$$
\begin{gathered}
\Delta \varphi=-2 \pi \frac{\mathrm{L}}{\lambda} \cos \theta_{\mathrm{rg}}, \\
\mathrm{d}=\min \left|\theta_{r g}-\theta_{i}\right|
\end{gathered}
$$

The value $\theta_{i}$ for which variable $\mathrm{d}$ obtains a minimum value is the desired value.

It proposed a parallel method for determining the coordinates of your location.

1. Calculated the value of the phase shift $\Delta \varphi=\Delta \varphi^{\prime}+\Delta \varphi^{\prime \prime}$;

2. Determine values $\theta_{\mathrm{i}}, \mathrm{R}_{\mathrm{i}}$, in the strip, $\Delta \theta_{i}, \Delta \mathrm{R}_{i}$, $10^{0} i<\theta_{\mathrm{i}}<10^{0}(i+1), i=1 . .17, \mathrm{R}_{\mathrm{i}}=\mathrm{R}_{\mathrm{NFR}}+\left(\mathrm{R}_{\mathrm{FFR}}-\mathrm{R}_{\mathrm{NFR}}\right) / i$,

3. For the current strip is defined value $\Delta \theta_{i}, \Delta R_{i}$, find a pair of $\theta_{i}, R_{i}$ using a Hook-Jeeves method. 
4. Using the rejection operation (13), (14) we obtain the required values of $\theta, R$.

\section{Results}

1. The analysis of the theoretical and practical aspects of the determination of the RES position on the curvature of the receiving front of the EMW is conducted.

2. The conditions of solvability of the equation for determining the RES positioning are obtained, the practical aspects of applying the algorithm of the consistent determinate positioning are studied.

3. On account of the equation determining the position value of the instrumental error of the phase shift measurement the algorithm of the parallel determination of RES is suggested. 4. A method for determining the position of RES on the basis of a multi-dimensional search method that has a higher accuracy of the RES position is suggested.

\section{Conclusions}

1. The growth of TCS increases the number of RES. It can be argued that every object can be a secondary source of radio emissions. Thanks to these radiations the location of the object can be stabilized.

2. The successful solution of the task of determining the location of objects on the secondary radiation parameters allowing us to stop using expensive satellite navigation systems.

3. This method can be implemented in the searching devices for so called "harmful sources" of any radio emissions range of both standalone and as a part of TCS systems.

4. Implementation of the method in TCS first of all involves the improvement of software, and there are no problems with the implementation of hardware.

\section{References}

1. Slobodyaniuk P.V., Blagodarnyi V.G., Stupak V.S.

Reference book of the radiomonitoring/ Under the editorship of Slobodyaniuk P.V. - Kyiv, 2008. - 583 p.

2.Avdeenko G.L., Fedorov V.I., Yakornov E.A. Determination of the location of the radio source on the curvature of the electromagnetic wave front. News of the universities. Radioelectronics. - 2008. № 3. - p. 3-11.

3. Avdeenko G.L., Lipchevskaya I.L., Yakornov E.A. Phase systems of the positioning of the radio wave signal in the Frenel zone. News of the universities. Radioelectronics. 2012. № 2. - p. 24-33.

4. I.Y. Kremer and others. Spatial signal processing. M. Radio and Communication 1984.-224 p.

5. R. Hooke, T.A. Jeeves, "Direct Search solutions for numeral and static problems", 212-219 p. 1961

Received in final form on September 16, 2016

\section{Якорнов С.А., Цуканов, О.Ф.}

Уточнений метод визначення місця розташування джерела радіовипромінювання по криволінійному фронту хвилі

Проблематика. Не дивлячись на обмежену дальність дії, пристрої визначення місця розташування джерела радіовипромінювання по криволінійному фронту електромагнітної хвилі, дозволяють за допомогою рознесеної антенної системи вирішувати завдання одночасного визначення дальності та напрямку джерела радіовипромінювання на основі врахування кривизни фронту прийнятої електромагнітної хвилі. Для визначення кутового напрямку обчислюється фазовий зсув який виникає за рахунок різниці ходу прийнятого фронту електромагнітної хвилі, а за рахунок криволінійного фронту хвилі визначається дальность. При цьому завдання вирішується в два етапи, на першому визначається кутова напрямок, а на другому - дальність тому метод не має високу точність.

Мета досліджень. Розробка методу одночасного визначення місця розташування джерела радіовипромінювання за результатами вимірювання фазових зрушень який, крім того дозволяє підвищити точність визначення місця розташування.

Методика реалізації. Запропонований метод заснований на використанні уточненої форми вираження для визначення дальності та кутового напрямку за результатами вимірювання фазових зсувів, в тому числі за рахунок криволінійного фронту електромагнітної хвилі. Шукані параметри визначаються шляхом пошуку безумовного локального екстремуму нелінійного виразу для визначення дальності та кутового напрямку методом Хука-Дживса.

Результати досліджень. Запропонований метод визначення місця розташування, дозволяє одночасно визначати джерела радіовипромінювання та підвищити точність визначення місця розташування в порівнянні 3 існуючими методами на 3-8\%.

Висновки. Метод може бути легко реалізований як в пристроях пошуку джерел радіовипромінювань в широкому діапазоні частот як існуючих так і в перспективних телекомунікаційних системах. 
Ключові слова: криволінійний фронт хвилі; фазовий зсув; джерело радіовипромінювання; антенна система; довжина хвилі; кутовий напрямок; дальність джерела радіовипромінювання; метод Хука-Дживса.

Якорнов Е.А., Цуканов О.Ф.

Уточненный метод определения местоположению источника радиоизлучения по криволинейному фронту волны Проблематика. Не смотря на ограниченную дальность действия, устройства определения местоположения источника радиоизлучения по криволинейному фронту электромагнитной волны, позволяют с помощью разнесенной антенной системы решать задачу одновременного определения дальности и направления источника радиоизлучения на основе учета кривизны фронта принимаемой электромагнитной волны. Для определения углового направления вычисляется фазовый сдвиг возникающий за счет разности хода принимаемого фронта электромагнитной волны, а дальности - за счет криволинейного фронта волны. При этом задача решается в два этапа, на первом - определяется угловое направление, а на втором - дальность поэтому метод не обладает высокой точностью.

Цель исследований. Разработка метода одновременного определения местоположения источника радиоизлучения по результатам измерения фазовых сдвигов который, кроме того позволяет повысить точность определения местоположения. Методика реализации. Предлагаемый метод основан на использовании уточненной формы выражения для определения дальности и углового направления по результатам измерения фазовых сдвигов, в том числе и за счет криволинейного фронта электромагнитной волны. Искомые параметры определяются путем поиска безусловного локального экстремума нелинейного выражения для определения дальности и углового направления методом ХукаДживса.

Результаты исследований. Предложенный метод определения местоположения, позволяет одновременно определять параметры источника радиоизлучения и повысить точность определения местоположения по сравнению с существующими методами на $3-8 \%$.

Выводы. Метод может быть легко реализован как в устройствах поиска источников радиоизлучений в широком диапазоне частот как существующих так и в перспективных телекоммуникационных системах.

Ключевые слова: криволинейный фронт волны; фазовый сдвиг; источник радиоизлучения; антенная система; длина волны; угловое направление; дальность источника радиоизлучения; метод Хука-Дживса. 